\title{
Census Declaration from Arsinoite Nome
}

\section{Ibrahim Mohamed EI Said Mohamed Abdou}

Lecturer - Ancient European Civilization Department

- Ain Shams University Faculty of Arts

ibrahim.alsaid@art.asu.edu.eg

\begin{abstract}
The current paper is an edition of unpublished Greek documentary papyrus from Cairo Museum under glass 86 of the Special Register Nr. 3049 with inv. 158. This papyrus is attributed to Theadelphia (Arsinoite nome) and dates to the first half of the second century $\mathrm{AD}$. This text is a census declaration, the Roman government set up a fourteen-year cycle of census declarations. Each inhabitant in Egypt had to be declared in a house-by-house. The verso of the papyrus was later used for a memorandum.
\end{abstract}

Keywords: Greek Papyri, Arsinoite Nome, Demography of Roman Egypt.

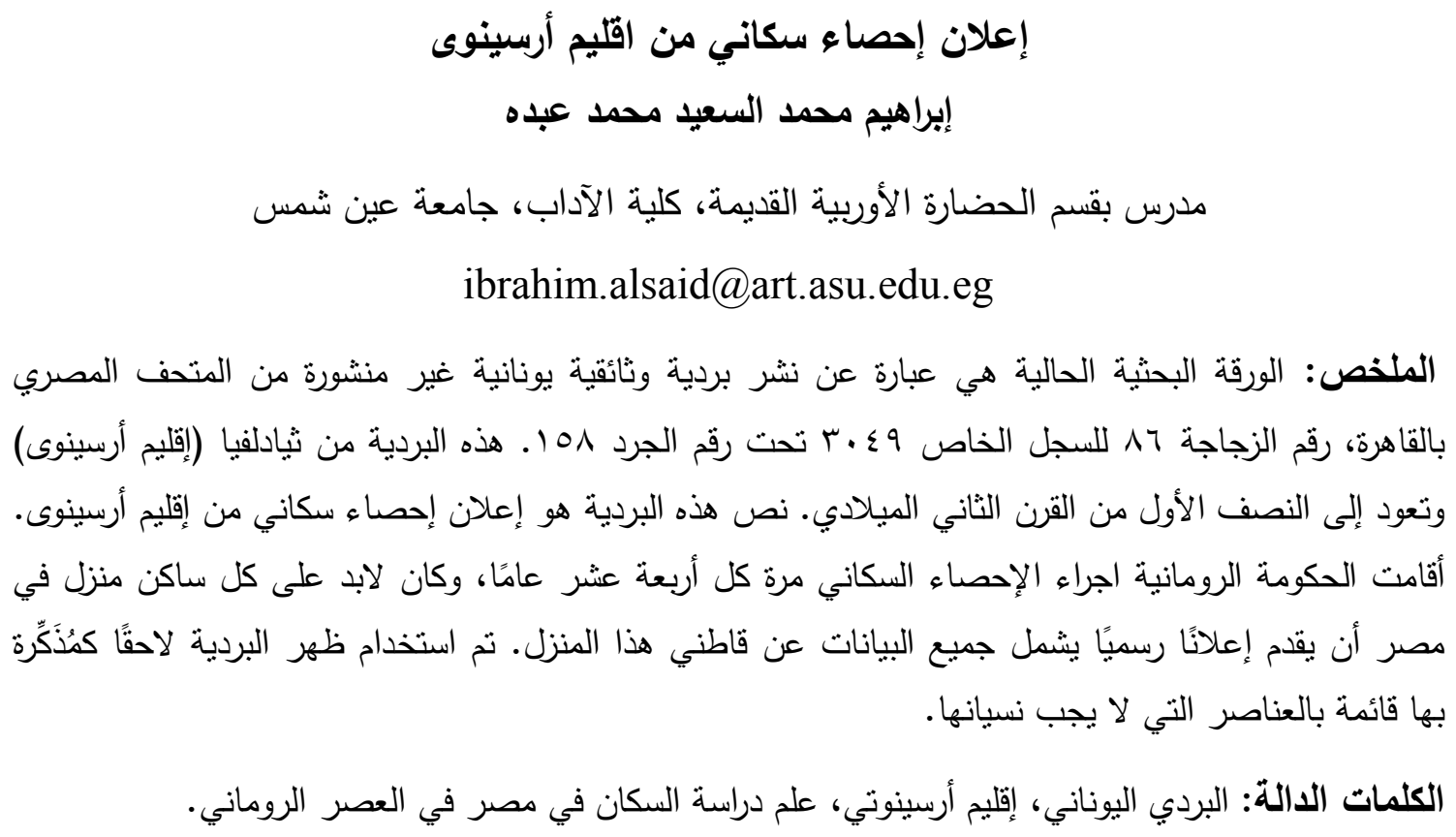


The papyrus consists of two fragments. It has been irregularly cut off on all sides. The recto and verso are written by different hands. The text on the recto is written by a legible hand, along the fibers, in 29 lines. There are remains of two margins on the recto; at the top $1 \mathrm{~cm}$, and at the lower $1 \mathrm{~cm}$. The text on the verso is written by a semicursive hand, across the fibers, in 18 lines. There are remains of two margins on the verso; at the top $3 \mathrm{~cm}$, and at the lower $4 \mathrm{~cm}$. The papyrus has suffered not only lacunae, but also the partial decay of the material and the ink is in places only faintly discernible. The text consists of two pieces materially joined; the two pieces came from the same papyrus roll. The beginnings and the endings of the lines in this column have been lost. But a continuous text can be reconstructed by parallel declarations.

On palaeographical grounds, it can be dated to the first half of the second century $\mathrm{AD}$, due to palaeographical parallels, see: P. Fouad. 15 (Ptolemais Euergetis; AD 119, census return); P.Mich. III 178 (Bacchias; AD 119, census declaration); SB XVI 13288 (Theadelphia; AD 133, census register). For images see: http://papyri.info/ddbdp/.

The text is a census declaration on the recto, and the recto is a column number 2 of a

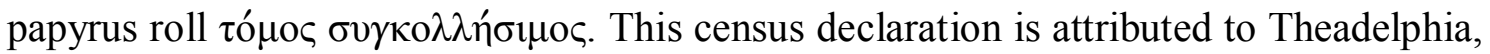
dated to the first half of the second century $\mathrm{AD}$, due to persons who were mentioned in the family's previous census return, see commentary 1 . 3. and may be referred to one census return from four successive censuses returns during the first half of the second century $\mathrm{AD}$ for years $103^{1}, 117^{2} ., 131^{3}$, and $145^{4}$. The census declarations dated to Roman era form the best documentary source of demographic information for the Roman Empire ${ }^{5}$. In Egypt the declarant was obliged to submit copies of his declaration

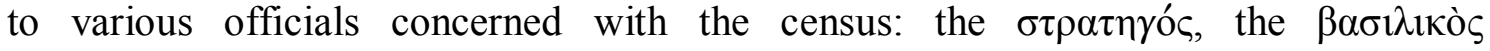

${ }^{1}$ SB XX 14303 (Ptolemais Euergetis; AD 103; Census declaration by house owners); SB XX 14309 (Ptolemais Euergetis; AD 103, Census declaration); Roger Bagnall, "Notes on Egyptian Census Declarations III.” BASP, no. 28 (1991): 121-133.

2 SB XXII 15464 (Arsinoite; AD 117, Census declaration); Roger Bagnall, "Census Declarations from the British library." CDE, 69, (1994): 109-126; P.Oxy. IV 786 (AD 117, Census declaration); Livia Capponi, "P.Oxy. IV 786: Conclusion of a Census-Return.” ZPE, no. 140 (2002): 177-180.

3 SB XX 14163 (Samaria; AD 131, Census declaration); Roger Bagnall, "Census Declarations from Tebtunis.” Aegyptus, no. 72 (1992): 61-84; SB XVIII 13288 (Theadelphia; AD 131, Census declaration); SB XXII 15336 (Arsinoite; AD 103, Census declaration); Roger Bagnall, "Notes on Egyptian Census Declarations V." BASP, no. 30 (1993): 35-56; Ruben Smolders, "SB XXII 15336 and the Interpretation of BGU IX 1897." ZPE, no. 148 (2004): 239-240.

4 SB XX 14111 (Arsinoite; AD 145, Census declaration); Orsolina Montevecchi, "Epikrisis e dichiarazioni di censimento di cateci arsinoiti." Aegyptus, no. 70 (1990): 27-31; SB XX 14304 (Herakleopolites; AD 145, Census declaration); Roger Bagnall, "Notes on Egyptian Census Declarations II.” BASP, no. 28, (1991): 13-32; SB XX 15465 (Oxyrhynchite; AD 145, Census declaration); SB XX 15466 (Oxyrhynchite; AD 145, Census declaration).

${ }^{5}$ Hin Saskia, "New light on Roman census papyri through semi-automated record linkage." Journal of Quantitative and Interdisciplinary History, no. 49 (2016): 50-65. 


\section{Census Declaration from Arsinoite Nome}

$\gamma \rho \alpha \mu \mu \alpha \tau \varepsilon v ́ \varsigma$, the $\kappa \omega \mu о \gamma \rho \alpha \mu \mu \alpha \tau \varepsilon \dot{c} \varsigma$ and the $\lambda \alpha о \gamma \rho \alpha \dot{\varphi} \varphi$ or of the village ${ }^{1}$. In the capital cities of the nomes, the declarations were addressed either to the two $\mu \eta \tau \rho о \pi$ ó $\lambda \varepsilon \omega \varsigma$

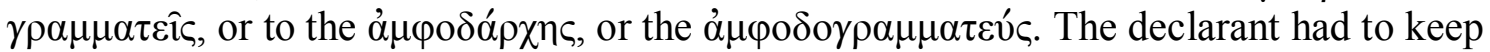
also for himself one or more copies for each of the bureau, and was obliged to purchase from five to ten sheets of papyrus for these reports ${ }^{2}$.

The scribe has written the abbreviations in different ways: The first way with a superscript letter, such as $\alpha \hat{v}^{\lambda}(\hat{\eta} \varsigma)$ lines $6,8,17, \dot{c}_{\varepsilon} \tau \varepsilon^{\lambda}(\varepsilon 1 \omega \dot{\theta} \theta \eta)$ line 29 and $\psi \varepsilon \iota^{\lambda}($ oṽ) lines 6 , 23,28 . The second way with a horizontal dash, such as $\mu$ ( $\tau \rho$ òc) lines $3,7,14,15,22$, 24, 26 and $\gamma \varepsilon \omega \rho \gamma(o ́ c)$ line 25. The third way with a curved vertical line, such as $\tau o ́(\pi \circ v)$ lines 6, 23, 28. See P.Wise. I 18 (Theadelphia; AD 146-147, property return).

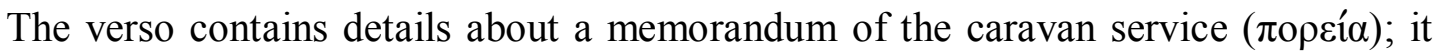
has a list of items not to be forgotten. The memorandum was made for personal use as an informal report. It was a written message that may be used for internal communication in a business, and it was written quickly hand and with abbreviated forms. The writer has started the body of the memorandum with a clear purpose, and he might make some mistakes.

\section{Text:}

Recto

$$
\begin{aligned}
& \mathrm{B} \longleftarrow
\end{aligned}
$$

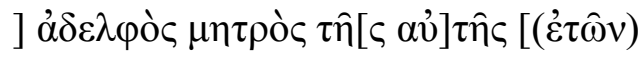

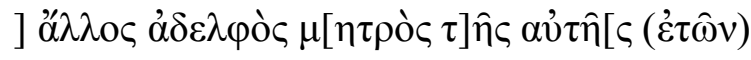

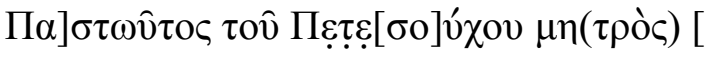

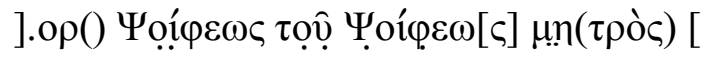

$$
\begin{aligned}
& 5 \text { a } \\
& \text { ] } \alpha u^{\prime} \lambda^{\prime}(\hat{\eta} \varsigma) \kappa \alpha \grave{~} \psi \varepsilon \iota^{\prime} \lambda^{\prime}(\mathrm{ov}) \tau o ́(\pi \mathrm{ov}) \text {. . . . . [ [ }
\end{aligned}
$$

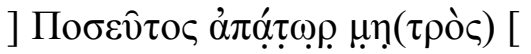

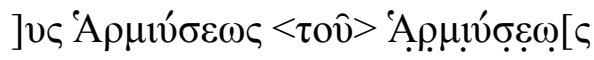

$$
\begin{aligned}
& \text { ] } \alpha u^{\prime} \lambda^{\prime}(\hat{\eta} \varsigma) \pi \alpha \tau \rho ı \kappa(\hat{\eta} \varsigma) \kappa o 1[v] \omega[v] ı \hat{n} \varsigma[
\end{aligned}
$$

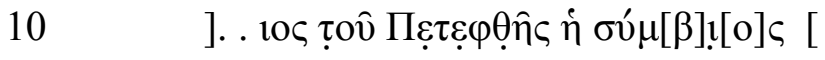

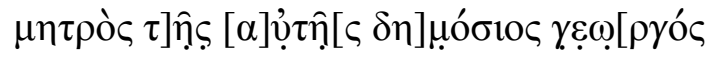

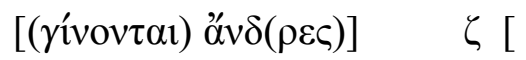

$$
\begin{aligned}
& \text { ]... [ ] ] }
\end{aligned}
$$

${ }^{1}$ Sayed Omar, “Sechs Zensus-Eingaben aus Theadelphia (P. Kairo Museum SR 3049/69-74).” BACPS, no. 1 (1985): 37-50; Graham Claytor and Roger Bagnall, "The beginnings of the Roman provincial census: a new declaration from 3 BCE." Greek, Roman and Byzantine Studies, no. 55 (2015): 637653.

2 Sayed Omar, “Two Documents from Cairo Museum.” BACPS, no. 27 (2010): 13-21; Sabine Huebner, Papyri and the Social World of the New Testament (London: Cambridge University Press, 2019), 37 43. 
15

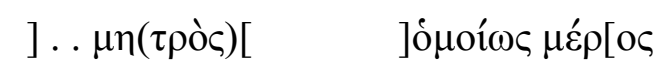

].ıк $\quad$ a $\quad$

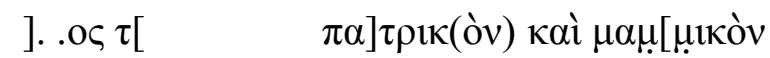

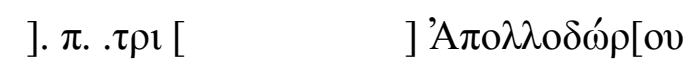

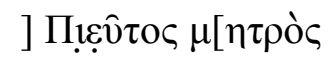

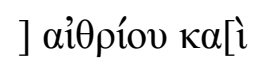

20

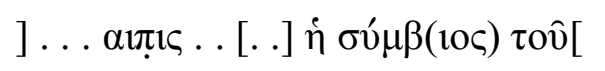

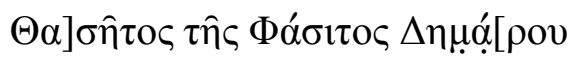

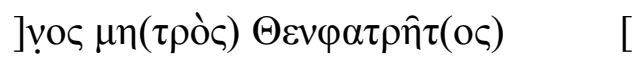

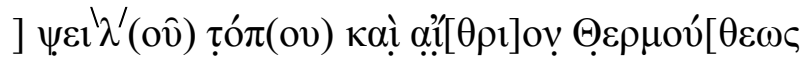

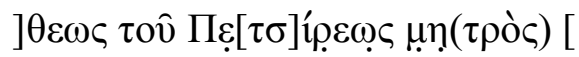

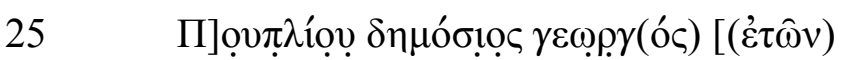

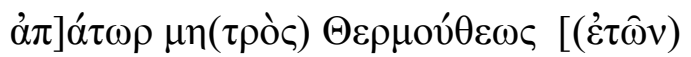

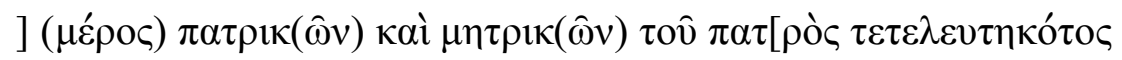

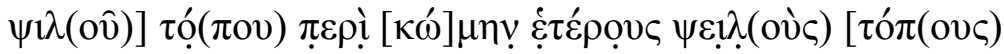

] $\dot{\epsilon \varepsilon \lambda(\varepsilon เ \omega ́ \theta \eta) \delta 1[\alpha ́] \Delta \eta \mu \alpha ́ \rho ̣ o v ~}$

Verso

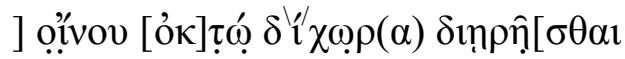

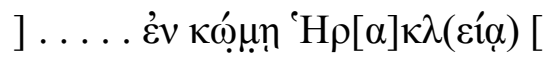

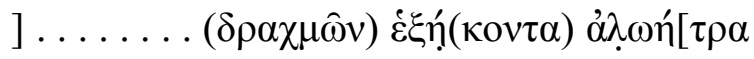

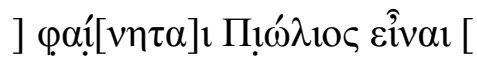

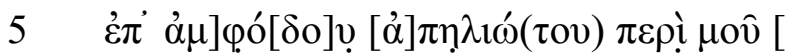

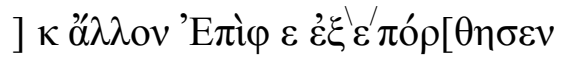

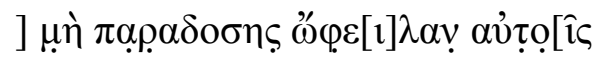

]$\rho \omega \ldots[\ldots] \ldots[\ldots] \ldots[$

$\varepsilon] \operatorname{i\sigma ǵt} \tilde{\rho}[\alpha \xi \varepsilon v \ldots \ldots \ldots \ldots$

$10 \quad \mathrm{~A}] \rho \varphi \hat{v} \tau \mathrm{o}[\varsigma \ldots \ldots] \ldots[$

$\sigma v \mu] \pi \lambda \varepsilon^{\prime} \rho \omega \sigma\left[1 v \ldots \delta \varepsilon^{\prime}\right] \gamma \rho<\alpha>\psi(\varepsilon) \varphi .1[$

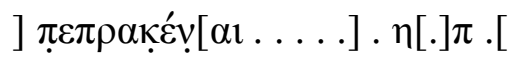

o]. $[v] \varepsilon \mu \pi[o ́] \rho o[v$

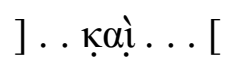

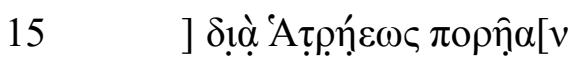

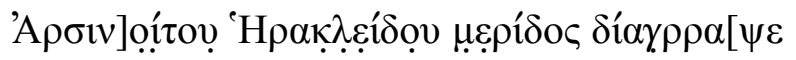

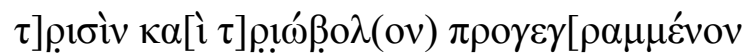




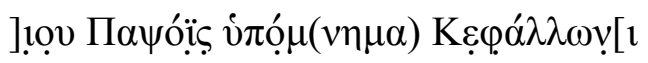

\section{Corrections:}

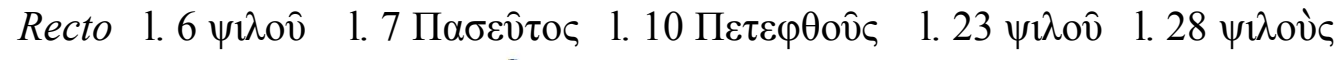

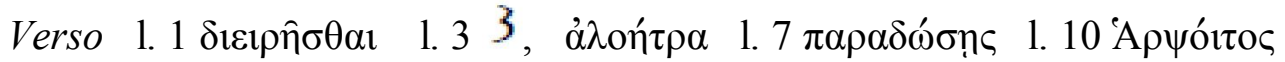

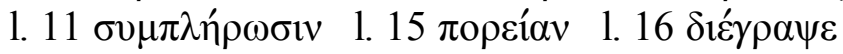

\section{Translation:}

Recto

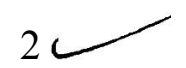

brother of the same mother, aged another brother, of the same mother, aged Pastous son of Petesouchus his mother is son of Psoiphis grandson of Psoiphis his mother is

5 his brother, of the same mother, aged of the courtyard and the vacant plot Paseus fatherless his mother is son of Harmiysis grandson of Harmiysis of the courtyard paternal (inheritance) owned in common with

10 grandson of Petephthous the wife the same mother, a cultivator of state ...... total 7 men

his mother is ......

his mother is ..... share likewise

$15 \ldots$... brother his mother is .... share .... paternal and grandmother (inheritance)

of the paternal courtyard .... Apollodorus

.... (grandson of) Pieus his mother is of an open courtyard and

$20 \quad \ldots . \ldots$ the wife of

Thases daughter of Phasis grandson of Demarus

his mother is Thenphatres

of the vacant plot and open courtyard of thermouthis

grandson of Petsiris his mother is

25 grandson of Pouplius, a cultivator of state, aged

fatherless his mother is thermouthis, aged

share of both paternal and maternal (inheritance from) the dead father of the vacant plot near the village, and other vacant plots

Verso

it has been accomplished through Demarus

they have divided eight dichora of wine

in the village Herakleia

sixty drachmae (for the costs of) threshing

he appears to be Piolis

5 in the eastern quarter near me

he pillaged 20 and the other 5 (in the month) Epiph 


\section{Census Declaration from Arsinoite Nome}

you shall not hand over (the amount) owed to them

.....

of Harpsois

the completion .... he paid

I have sold

of the wine-merchant

.........

15 through the caravan of Hatres

of the Arsinoite nome, Herakleides division, he paid

three and three obols the above mentioned

memorandum of . . . son of . . . grandson of Papsois to Kephallon

\section{Commentary:}

: It filled in empty space at the ends of lines to prevent uncalled-for additions and forgery.

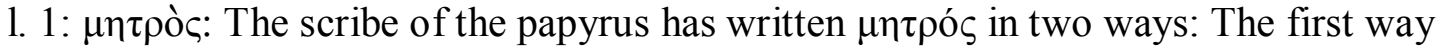
with a word has been written out in full, see lines 2 , and 5 . the second way with a word has been written as a symbol, see lines 22 and 26.

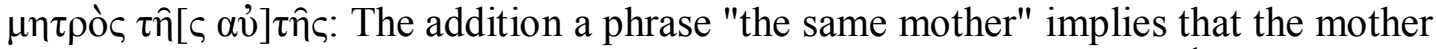
is the same, probably the father died, and the mother married another one ${ }^{1}$.

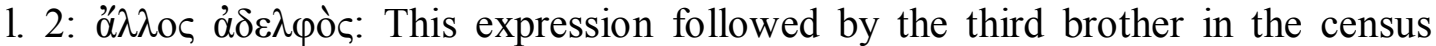
return, see: P.Corn. 22, Col. III (Philadelphia; AD 25-50), 11. 74-76 (census roll):

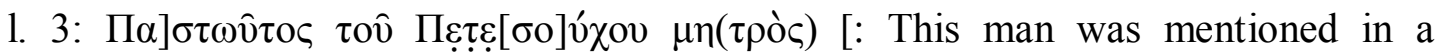
previous census return from Theadelphia; see: BGU IV 1072 (Theadelphia; AD 128), 11. 6-7 (a dowry declaration):

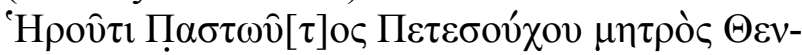

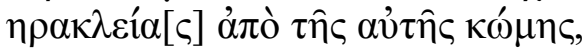

Herous son of Pastous and grandson of Petesouchus his mother is Theneraklea

1. 6: $\psi \varepsilon \iota^{\prime} \lambda^{\prime}(\mathrm{ov}) \tau o ́(\pi \mathrm{ov})$ : This place is located within the urban communities or in their vicinity $(\pi \varepsilon \rho \grave{i} \kappa \omega \mu \eta \nu)$, and it has formed an intermediate area between the village and

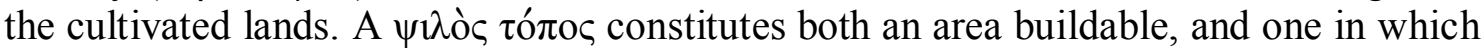
the building is demolished or falls into ruins: therefore it is not a $\psi i \lambda$ ó $\varsigma$ land in an absolute sense, but it can also contain ruins and rubble ${ }^{2}$. The declarations were

\footnotetext{
${ }^{1}$ Nadine Quenouille, Edition und Kommentar neuer Papyri aus den französisch-italienischen Grabungen in Tebtynis (̈̈gypten), (P.Tebt. Quen.), (Trier: University of Leipzig, 2012), 98.

2 Klaus Maresch, Bronze und Silber: Papyrologische Beiträge zur Geschichte der Währung im ptolemäischen und römischen Ägypten bis zum 2. Jahrhundert n. Chr., Papyrologica Coloniensia 25, (Germany: Verlag für Sozialwissenschaften, 1996), 87-88; Isabella Bonati, Il lessico dei vasi e dei contenitori greci nei papyri: Specimina per un repertorio lessicale degli angionimi greci, Archiv für Papyrusforschung und verwandte Gebiete - Beihefte 3 (Germany: de Gruyter, 2016), 32, 55-58.
} 


\section{Census Declaration from Arsinoite Nome}

submitted when a general census of property was ordered by the prefect: $\kappa \alpha \tau \grave{\alpha} \tau \grave{\alpha}$

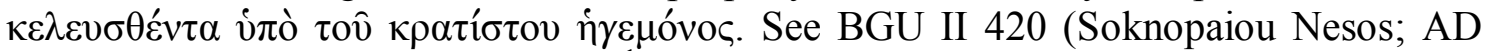
130-131), 11. 6-7 (census declaration) ${ }^{1}$.

1. 7: $\alpha \dot{\alpha} \alpha \dot{\tau} \tau \omega \rho$ : The expression $\alpha \dot{\alpha} \alpha \dot{\tau} \omega \rho$ was used to distinguish the legal status of illegitimate children ${ }^{2}$.

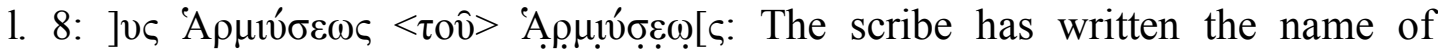
grandfather without $\tau$ oṽ, although he had written $\tau$ ov with the name of grandfather in the lines 3, 4, 10 and 24.

1. 9:] $\alpha v^{\prime} \lambda^{\prime}(\hat{\eta} \varsigma) \pi \alpha \tau \rho \iota \kappa(\hat{\eta} \varsigma) \kappa o \imath[v] \omega[v] ı n \hat{s} \varsigma$ [: For the closest parallel wording, see: SB XX 14164 (Talei; AD 160), 11. 8-10 (Census declaration):

$$
\dot{\varepsilon}[v \tau \hat{n} \alpha u ̛ \tau \hat{]}]
$$

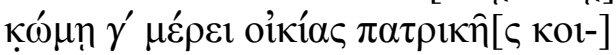

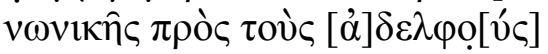

in the same village, 3rd share of a paternal house, owned in common with my brothers.

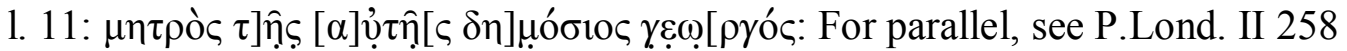
(Arsinoite; AD 94), 1. 58 (Census declaration).

1. 12: $\zeta$ : There is an indication that seven persons were listed in the previous lines. For parallel form, see: P.Congr. XV. 14 (Philadelphia; AD 46-47), 1. 27 (Census list):

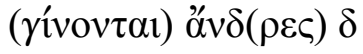

total 4 men

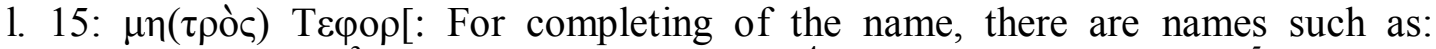

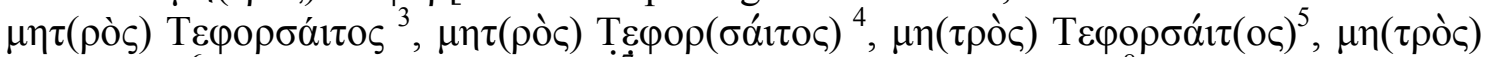

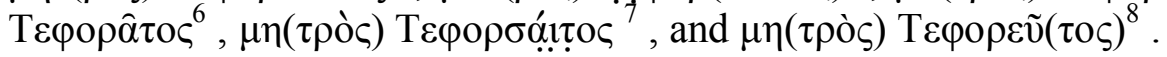

${ }^{1}$ James Keenan \& Joseph Manning, \& Uri Yiftach, Law and Legal Practice in Egypt from Alexander to the Arab Conquest, A Selection of Papyrological Sources in Translation, with Introductions and Commentary (London: Cambridge University Press, 2014), 74.

${ }^{2}$ Uri Yiftach, "Apator metros: The Rise of a Formula in Bureaucratic Perspective." In Symposion 2015: Vorträge zur griechischen und hellenistischen Rechtsgeschichte, 1-4 September 2015 (Serbia: Coimbra, 2016), 115-120, Myrto Malouta, "Families, Households, and Children in Roman Egypt." in Riggs, C. (ed.) Oxford Handbook of Roman Egypt (London: Oxford University Press, 2012), 288-304; Maria Nowak, "The Fatherless and Family Structure in Roman Egypt.” In Symposion 2015: Vorträge zur griechischen und hellenistischen Rechtsgeschichte, 1-4 September 2015 (Serbia: Coimbra, 2016), 99-114.

${ }^{3}$ P.Col. 2 1-r-1b, Col. IV (Theadelphia; AD 134-135), 1. 5 (report of taxation).

${ }^{4}$ P.Col. 2 1-r-1a, Col. VII (Theadelphia; AD 134-135), 1.18 (report of taxation).

${ }^{5}$ BGU IX 1891, Col. IX (Theadelphia; AD 134), 1. 280 (report of taxation).

${ }^{6}$ BGU IX 1891, Col. IX (Theadelphia; AD 134), 1. 292 (report of taxation).

${ }^{7}$ BGU IX 1891, Col. XI (Theadelphia; AD 134), 1. 332 (report of taxation).

${ }^{8}$ BGU IX 1891, Col. XII (Theadelphia; AD 134), 1. 372 (report of taxation). 


\section{Census Declaration from Arsinoite Nome}

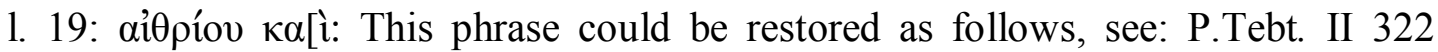
(Tebtynis; AD 189), 11. 8-9 (Census declaration):

$$
\text { vं } \alpha^{\prime} \rho \chi \varepsilon 1 \mu \mathrm{ol} \dot{\varepsilon} \pi^{\prime} \dot{\alpha} \mu-
$$

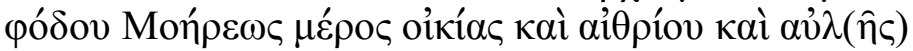

I own in the Moeris quarter a share of a house and open courtyard, and

courtyard.

Husson shows that $\alpha i \theta \rho i o v$ and $\alpha v^{\prime} \lambda \eta$ are the two Greek terms used for "courtyard" in

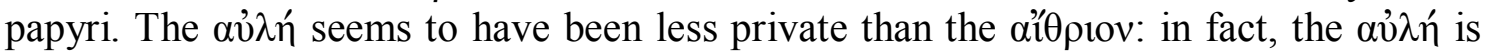
often defined as adjacent $(\pi \rho \circ \sigma o v \sigma \alpha \alpha)$, showing that it was placed on a side of the house and not at the center of it. Those outside the family could also rent the $\alpha \hat{\nu} \lambda$ n $^{\text {of a house }}{ }^{1}$. The $\alpha$ i $\theta$ prov was in a central position in the house; it never appears as being rented to someone else. Therefore, the $\alpha i \theta \rho 10 v$ was the private courtyard of the house which gave access to private rooms. While the $\alpha \hat{\jmath} \lambda \eta ́$ was likely used for household activities ${ }^{2}$.

The courtyard was the center of activity and socialization for the members of the family. Ovens made of mud and built into the wall of the courtyard, grain bins and millstones used by those making bread for the household, and cooking is believed to have taken place in the open courtyard. Various instruments for spinning and weaving have been found, as well as tools for making wooden domestic utensils and simple furnishings. Domestic animals were also kept in the courtyard ${ }^{3}$. The $\alpha i^{\prime} \theta \rho i o v$ includes in the list of dwelling-rooms, on the possibility of it having a flat roof and that there was also another inhabitable space on a higher floor, see: P. Monts. Roca IV 78 (Oxyrhynchos; AD 49-54), 11. 9-10 (loan of money):

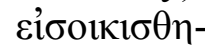

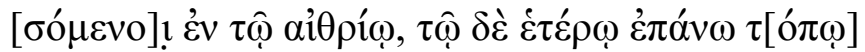

They will live in the open courtyard, and on the second floor above.

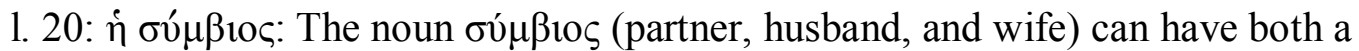
masculine and a feminine article ${ }^{4}$. For a feminine article, see: P.Oxy. XXXI 2559 (AD 100-200), 11. 12-13 (letter of Arrius eudaimon).

For a masculine article, see: P.Oxy. XLVI 3312 (AD 100-200), 11. 8-10 (private letter).

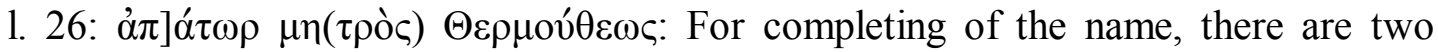
possibilities, it could be one of them, the first possibility, see: BGU IX 1891 (Theadelphia; AD 134-135), 1.73 (financial reports of the collectors of money taxes):

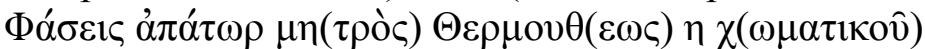

Phaseis fatherless his mother is Thermouthis, dike tax 8.

${ }^{1}$ Geneviève Husson, OIKIA. Le vocabulaire de la maison privée en Égypte d'après les papyrus grecs, (Paris: Sorbonne, 1983), 29-36; Geneviève Husson; "Houses in Syene in the Patermouthis archive," BASP, no. 27 (1990): 123-137; Robert Daniel, Architectural orientation in the papyri (Paderborn: Schöningh, 2010), 123-147,

2 Ada Nifosi, Becoming a Woman and Mother in Greco-Roman Egypt: Women's Bodies, Society and Domestic Space (London: Routledge, 2019), 184.

${ }^{3}$ Sabine Huebner, The Family in Roman Egypt: A Comparative Approach to Intergenerational Solidarity and Conflict (London: Cambridge University Press, 2013), 41-42.

${ }^{4}$ Peter Head, "Epistolary Greetings in the Oxyrhynchus Papyri," Tyndale Bulletin, no. 70 (2019): 269290. 


\section{Census Declaration from Arsinoite Nome}

The second possibility, see: BGU IX 1891 (Theadelphia; AD 133), 1.6 (census return):

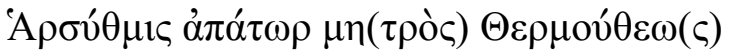

Harsythmis fatherless his mother is Thermouthis

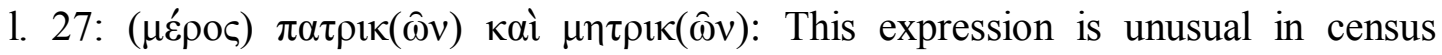
declarations, but it can be restored, cf. P.Rein. I 46 (Soknopaiou Nesos; AD 189), 11. 1819 (Census declaration).

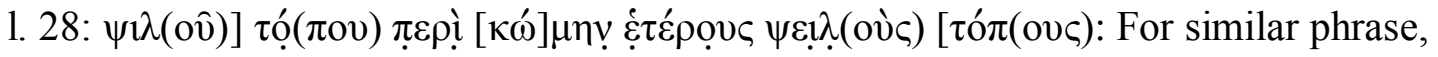
see: P.Harr. I 71 (Oxyrhynchus; AD 189), 11. 19-20 (Census Return):

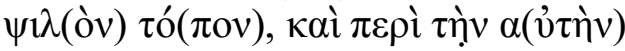

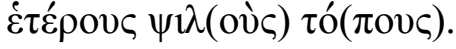

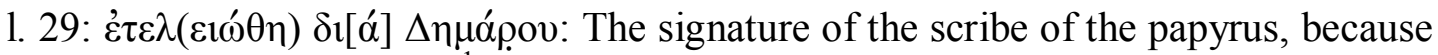
the signature makes it original ${ }^{1}$.

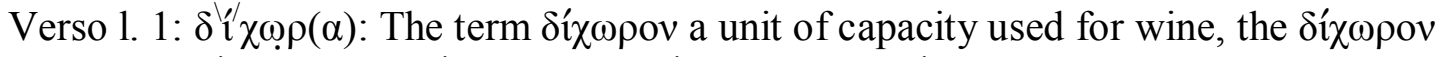

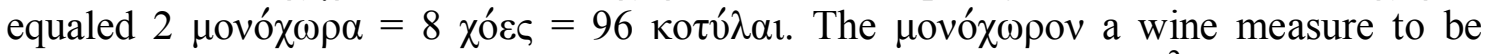
equivalent to about 7.3 liters, and that a donkey load was $8 \mu$ ovó $\chi \omega \rho \alpha^{2}$.

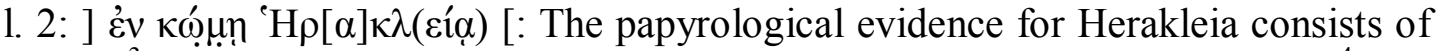
144 texts $^{3}$, ranging from the mid-third century B.C. to the eighth century $\mathrm{AD}^{4}$, the village of Herakleia is situated in the division of Themistes of the Arsinoite nome. Herakleia was somewhere near the southern border of Lake Moeris, close to the meris of Herakleides and Soknopaiou Nesos. As the lake has shrunk considerably over time, it may well have been on the southern shore of the lake in antiquity ${ }^{5}$.

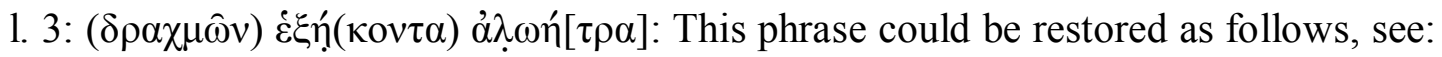
P.Theon. 25 (Oxyrhynchite; AD 160), 11. 6-8 (payment application): $\delta \rho \alpha \chi \mu \grave{\alpha} \varsigma$

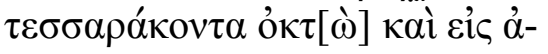

${ }^{1}$ Carolin Arlt, "The Egyptian Notary Offices in the Ptolemaic Fayum." In Graeco-Roman Fayum-Texts and Archaeology, edited by S. Lippert and M. Schentuleit (Germany: Wiesbaden, 2008): 15-26; Graham Claytor, Mechanics of Empire: the Karanis Register and the Writing Offices of Roman Egypt (Michigan: University of Michigan, 2014): 176.

${ }^{2}$ Nico Kruit \& Klaas Worp, "Metrological Notes on Measures and Containers of Liquids in GraecoRoman and Byzantine Egypt," APF, no. 45 (1999): 96-127; Philip Mayerson, "The Monochoron and Dichoron: the Oxyrhynchition," ZPE, no. 131 (2000): 169-172; Philip Mayerson, "Standardization of Wine Measures at Oxyrhynchus in the Third Century A.D. and its Extension to the Fayum," BASP, no. 37 (2000): 105-109; Taco Terpstra, "A Third-Century CE List of Wine from Five Estates", BASP, no. 49 (2012): 109-118.

${ }^{3}$ https://papyri.info/search?PLACE=Herakleia\%20(Arsinoites)

${ }^{4}$ P.Cair.Zen. IV 59656 (Herakleia, BC 256-248), 1.4 (Memorandum); SB XXII 15729 (Herakleia; AD 639), 1.9 (Lease); Deborah Hobson, "The Village of Heraklia in the Arsinoite Nome”, BASP, no. 22 (1985): 101-115.

${ }^{5}$ Deborah Hobson, “The Inhabitants of Heraklia,”BASP, no. 23 (1986): 99-123. 


\section{Census Declaration from Arsinoite Nome}

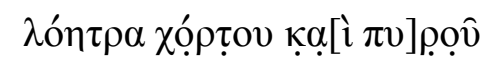

forty-eight drachmae and for the costs of threshing the grass and the wheat

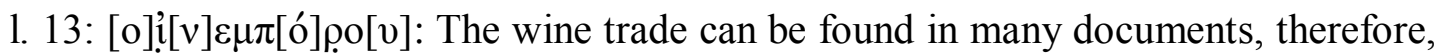

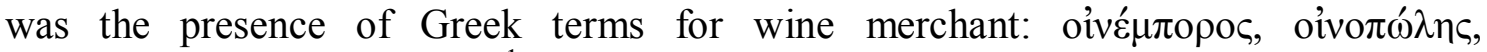

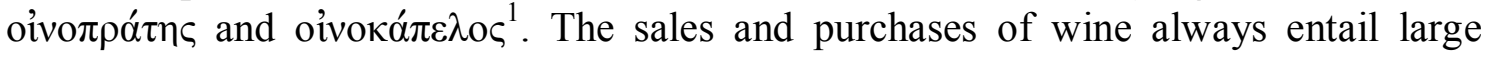
amounts P.Oxy. VII 1055 (AD 267), 11. 2-3 (Order for Delivery of Wine):

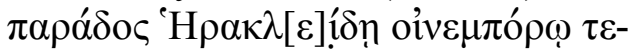

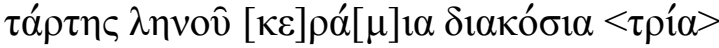

deliver to Heraclides, wine-merchant, two hundred and three jars from the fourth wine-tub.

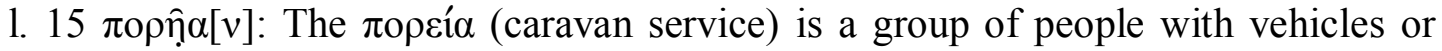
animals who travel together for safety through a dangerous area, especially across a desert. The caravans could easily be used upon the roads and tracks associated with irrigation channels by horse, camel, ox, or donkey. The caravans travel to the desert from the Nile Valley at Memphis, and from villages lying in the north of the Arsinoite nome, would travel through Soknopaiou Nesos, and the other villages of the nome were connected by routes to these important stations, and the Nile Valley, by other routes crossing a small section of desert in a direct line to the valley ${ }^{2}$. The caravan was used for the transport of crops, bulky commodities, passengers' transport of animals, transport of stones, and transport of military supplies ${ }^{3}$.

\section{Conclusion:}

Finally, it may be concluded:

- The papyrus offers new insight on the census declarations from Theadelphia.

- Their residents had mentioned in the family's previous census declarations from Theadelphia.

- The papyrus has preserved details about fatherless (ả $\pi \alpha ́ \tau \omega \rho)$.

- There is a description of the precise location of the property, such as: the

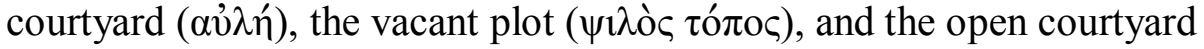
(aípiov).

- The papyrus gives papyrological evidence for the caravan service ( $\pi \circ \rho \varepsilon i ́ \alpha)$.

${ }^{1}$ Dorota Dzierzbicka, "Wine dealers and their networks in Roman and Byzantine Egypt. Some remarks"; in Proceedings of the 28th Congress of Papyrology, Barcelona 1-6 August 2016, ed. by Alberto Nodar \& Sofia Torallas Tovar (Barcelona: University of Barcelona, 2019): 510-524.

${ }^{2}$ Colin Adams, Land Transport in Roman Egypt; A Study of Economics and Administration in a Roman Province (London: Oxford University Press, 2007), 33; Fatma Hamouda, Communication and the Circulation of Letters in the Eastern Desert of Egypt during the Roman Period, Inaugural dissertation for attaining a doctorate from the Faculty of Philosophy of Heidelberg University (Heidelberg: Heidelberg University, 2018): 109-112.

${ }^{3}$ Adam Bülow-Jacobsen, "Communication, Travel, and Transportation in Egypt's Eastern Desert during Roman times (1st to 3rd century AD)," in H. Riemer, F. Förster (eds), Desert Road Archaeology in Ancient Egypt and Beyond. Africa Praehistorica 27 (Germany: Köln, 2013): 557-574. 

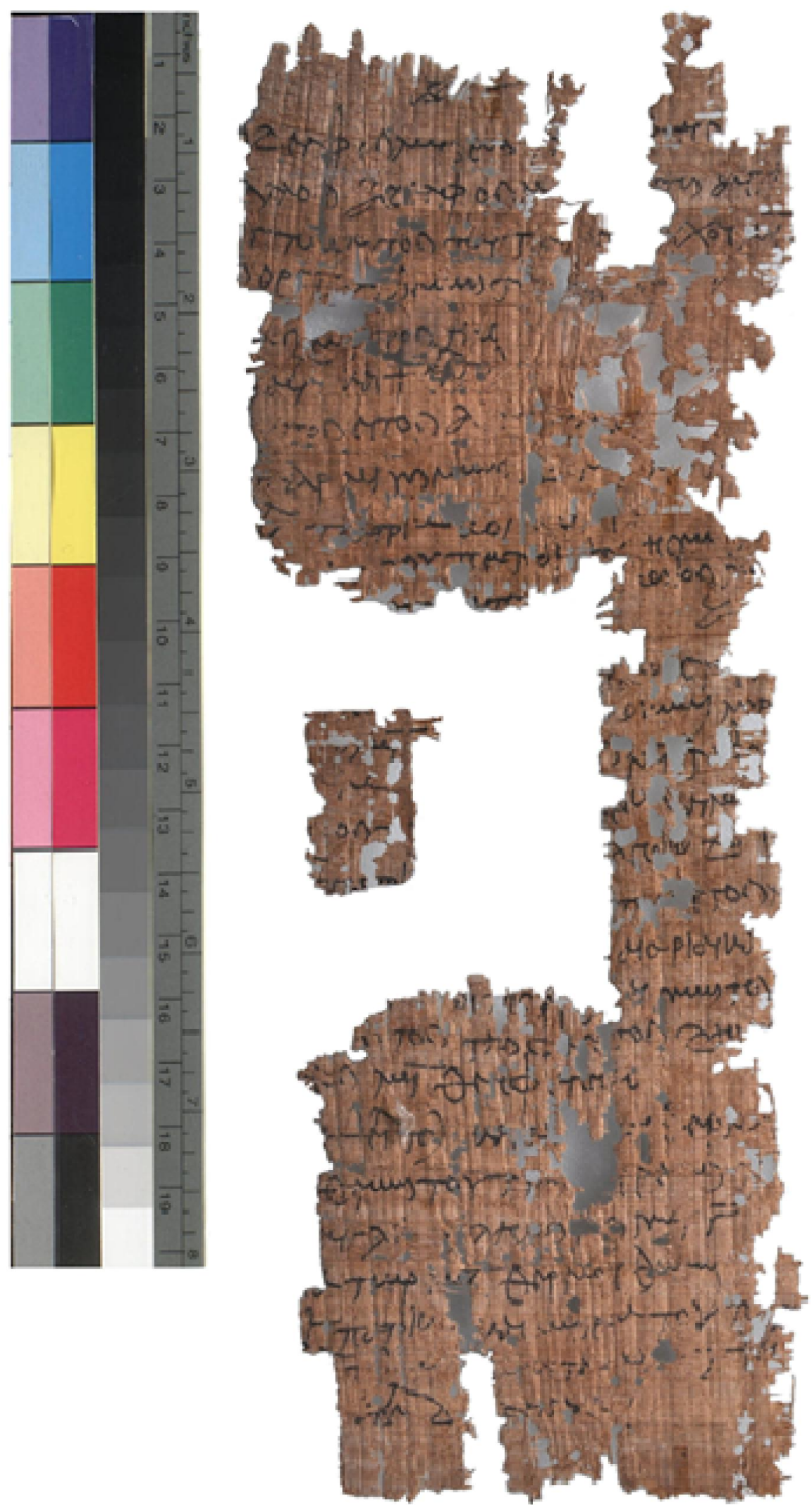

Egyptian Museum in Cairo under glass 86 of the Special Register Nr. 3049 with inv. 158 recto. 

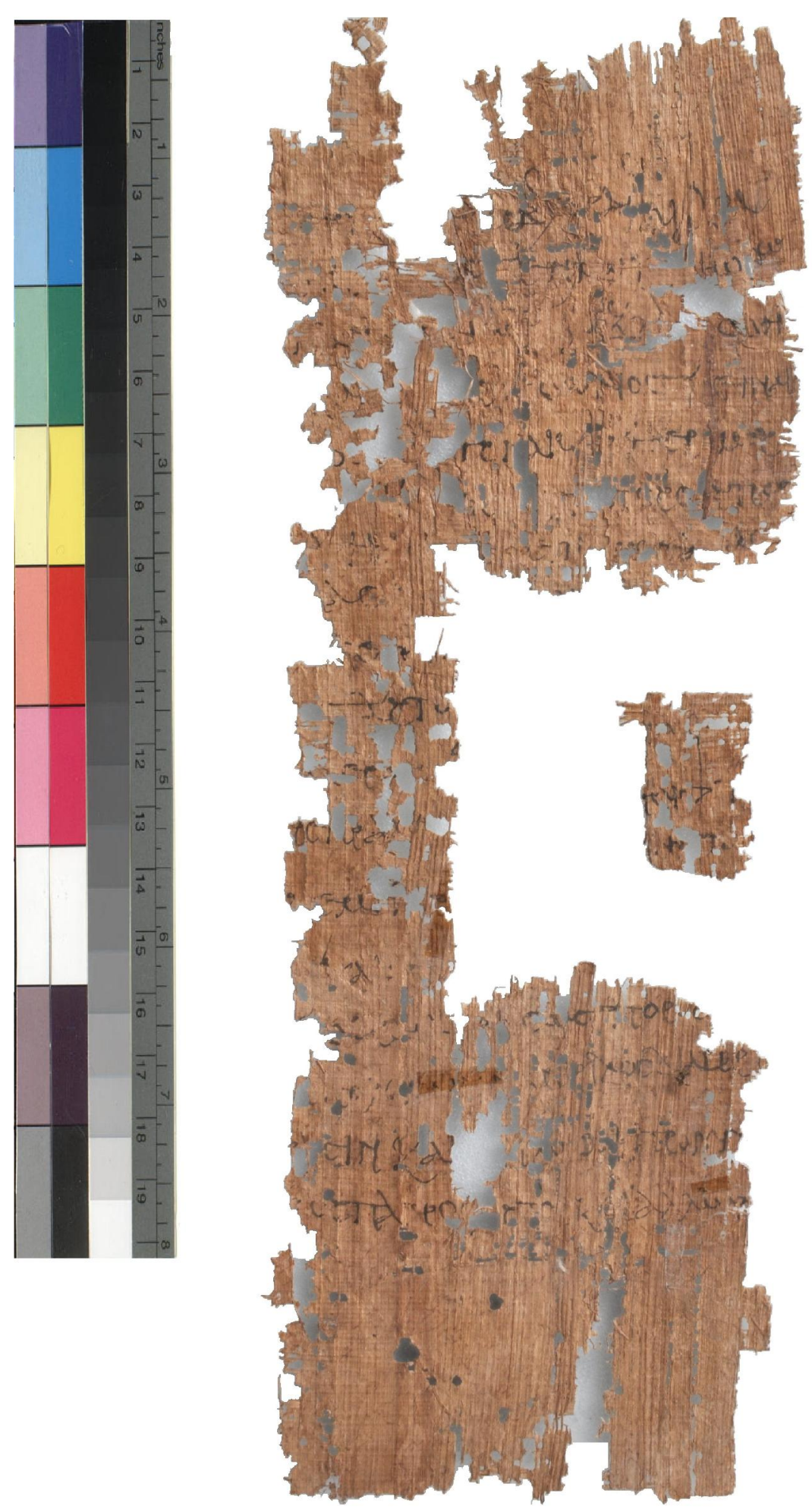

Egyptian Museum in Cairo under glass 86 of the Special Register Nr. 3049 with inv. 158 verso. 


\section{Bibliography}

- Adams, Colin. Land Transport in Roman Egypt; A Study of Economics and Administration in a Roman Province. London: Oxford University Press, 2007.

- Arlt, Carolin. "The Egyptian Notary Offices in the Ptolemaic Fayum." In GraecoRoman Fayum-Texts and Archaeology, edited by S. Lippert and M. Schentuleit. Germany: Wiesbaden (2008): 15-26.

- Bagnall, Roger. "Notes on Egyptian Census Declarations III." BASP, no. 28 (1991): 121-133.

-___ “Census Declarations from Tebtunis.” Aegyptus, no. 72 (1992): 61-84.

-__ "Notes on Egyptian Census Declarations V." BASP, no. 30 (1993): 35-56.

- _Census Declarations from the British library.” CDE, no. 69 (1994): 109-126.

- Bonati, Isabella. Il lessico dei vasi e dei contenitori greci nei papyri: Specimina per un repertorio lessicale degli angionimi greci, Archiv für Papyrusforschung und verwandte Gebiete - Beihefte 3. Germany: de Gruyter, 2016.

- Bülow-Jacobsen, Adam. "Communication, Travel, and Transportation in Egypt's Eastern Desert during Roman times ( $1^{\text {st }}$ to $3^{\text {rd }}$ century AD)." in H. Riemer, F. Förster (eds), Desert Road Archaeology in Ancient Egypt and Beyond. Africa Praehistorica 27. Germany: Köln (2013): 557-574.

- Capponi, Livia. "P.Oxy. IV 786: Conclusion of a Census-Return." ZPE, no. 140 (2002): 177-180.

- Claytor, Graham. Mechanics of Empire: the Karanis Register and the Writing Offices of Roman Egypt. Michigan: University of Michigan, 2014.

- Claytor, Graham. \& Bagnall, Roger. "The beginnings of the Roman provincial census: a new declaration from 3 BCE." Greek, Roman and Byzantine Studies, no. 55 (2015): 637-653.

- Daniel, Robert. Architectural orientation in the papyri. Paderborn: Schöningh, 2010.

- Dzierzbicka, Dorota. "Wine dealers and their networks in Roman and Byzantine Egypt. Some remarks"; in Proceedings of the 28th Congress of Papyrology, Barcelona 1-6 August 2016, ed. by Alberto Nodar \& Sofía Torallas Tovar. Barcelona: University of Barcelona, 2019: 510-524.

- Hamouda, Fatma. Communication and the Circulation of Letters in the Eastern Desert of Egypt during the Roman Period, Inaugural dissertation for attaining a doctorate from the Faculty of Philosophy of Heidelberg University. Heidelberg: Heidelberg University, 2018.

- Head, Peter. "Epistolary Greetings in the Oxyrhynchus Papyri." Tyndale Bulletin, no. 70 (2019): 269-290.

- Hobson, Deborah. "The Village of Heraklia in the Arsinoite Nome." BASP, no. 22 (1985): 101-115.

"The Inhabitants of Heraklia." BASP, no. 23 (1986): 99-123.

- Huebner, Sabine. The Family in Roman Egypt: A Comparative Approach to Intergenerational Solidarity and Conflict. London: Cambridge University Press, 2013.

- Papyri and the Social World of the New Testament. London: Cambridge University Press, 2019.

- Husson, Geneviève. OIKIA. Le vocabulaire de la maison privée en Égypte d'après les papyrus grecs. Paris: Sorbonne, 1983.

137.

"Houses in Syene in the Patermouthis archive." BASP, no.27 (1990): 123- 


\section{Census Declaration from Arsinoite Nome}

- Keenan, James. \& Manning, Joseph. \& Yiftach, Uri. Law and Legal Practice in Egypt from Alexander to the Arab Conquest, A Selection of Papyrological Sources in Translation, with Introductions and Commentary. London: Cambridge University Press, 2014.

- Kruit, Nico. \& Worp, Klaas. "Metrological Notes on Measures and Containers of Liquids in Graeco-Roman and Byzantine Egypt." APF, no. 45 (1999): 96-127.

- Malouta, Myrto. "The terminology of fatherless in Roman Egypt: $\alpha \pi \alpha \dot{\tau} \omega \rho$ and

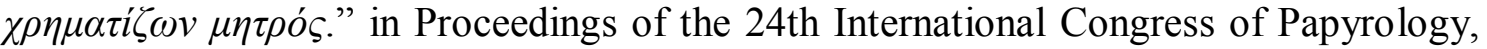
Helsinki, 1-7 August, 2004. Ed. J. Frösén, T. Purola, and E. Salmenkivi. Vol. 2. Societas Scientiarum Fennica, Commentationes Humanarum Litterarum, 122. Helsinki: 2007: 615-624.

- "Fatherless and formal identification in Roman Egypt." in Growing up Fatherless in Antiquity. Ed. S. Hübner and D. Ratzan. London: Cambridge University Press, 2009, 120-38.

- _Families, Households, and Children in Roman Egypt." in Riggs, C. (ed.)

Oxford Handbook of Roman Egypt. London: Oxford University Press, 2012: 288-304;

- Maresch, Klaus. Bronze und Silber: Papyrologische Beiträge zur Geschichte der Währung im ptolemäischen und römischen Ägypten bis zum 2. Jahrhundert $n$. Chr., Papyrologica Coloniensia 25. Germany: Verlag für Sozialwissenschaften, 1996.

- Mayerson, Philip. "The Monochoron and Dichoron: the Oxyrhynchition." ZPE, no. 131 (2000): 169-172.

- "Standardization of Wine Measures at Oxyrhynchus in the Third Century A.D. and its Extension to the Fayum." BASP, no. 37 (2000): 105-109.

- Montevecchi, Orsolina. "Epikrisis e dichiarazioni di censimento di cateci arsinoiti." Aegyptus, no. 70 (1990): 27-31.

- Nifosi, Ada. Becoming a Woman and Mother in Greco-Roman Egypt: Women's Bodies, Society and Domestic Space. London: Routledge, 2019.

- Nowak, Maria. "The Fatherless and Family Structure in Roman Egypt," In Symposion 2015: Vorträge zur griechischen und hellenistischen Rechtsgeschichte, 1-4 September 2015. Serbia: Coimbra, 2016: 99-114.

- Omar, Sayed. "Sechs Zensus-Eingaben aus Theadelphia (P. Kairo Museum SR 3049/69-74)." BACPS, no. 1 (1985): 37-50.

"Two Documents from Cairo Museum." BACPS, no. 27 (2010): 13-21.

- Quenouille, Nadine. Edition und Kommentar neuer Papyri aus den französischitalienischen Grabungen in Tebtynis (Ägypten) " (P.Tebt. Quen.). Trier: University of Leipzig, 2012.

- Saskia, Hin. "New light on Roman census papyri through semi-automated record linkage." Journal of Quantitative and Interdisciplinary History, no. 49 (2016): 50-65.

- Smolders, Ruben."SB XXII 15336 and the Interpretation of BGU IX 1897." ZPE, no. 148, (2004): 239-240.

- Taco Terpstra, "A Third-Century CE List of Wine from Five Estates.” BASP, no. 49 (2012): 109-118.

- Yiftach, Uri. "Apator metros: The Rise of a Formula in Bureaucratic Perspective." In Symposion 2015: Vorträge zur griechischen und hellenistischen Rechtsgeschichte, 1-4 September 2015. Serbia: Coimbra, 2016: 115-120. 